\title{
Idea gospodarki okrężnej w aspekcie odpadów z branż TSL i Automotive
}

Katarzyna Turoń

Studentka, Politechnika Śląska, Wydział Transportu, Katedra Budowy Pojazdów Samochodowych

Dagmara Golba

Doktorantka, Uniwersytet Jagielloński, Wydział Zarządzania i Komunikacji Społecznej, Instytut Spraw Publicznych

\section{Wstęp}

Społeczna odpowiedzialność biznesu (z języka angielskiego: corporate social responsibility) to idea, zgodnie, z którą przedsiębiorstwa w swojej działalności powinny kierować się nie tylko dążeniem do maksymalizacji zysku i własnym interesem, ale powinny wspierać rozwój społeczno-gospodarczy, a także przeciwdziałać swojemu negatywnemu wpływowi na środowisko, czy też społeczeństwo. Jedną z definicji zapisano w normie ISO 26000, charakterystycznym jej elementem jest wyróżnienie siedmiu obszarów społecznej odpowiedzialności biznesu ${ }^{1}$.

W literaturze przedmiotu odnaleźć można bardzo wiele różnorodnych definicji społecznej odpowiedzialności biznesu. Jedną z nich interesujących koncepcji CSR jest ta, którą zaproponował J. Elkington, tzw. triplebottomline, czyli zasada potrójnego fundamentu². Zakłada ona, że cele rozwojowe przedsiębiorstwa, jako systemu społeczno-ekonomicznego, powinny łączyć aspekty związane z zyskiem ekonomicznym, ludźmi tworzącymi organizacje oraz troskę o środowisko³. Definicja ta nawiązuje

ISO 26000, www.odpowiedzialnafirma.pl/o-csr/iso-26000 [dostęp online: 15.04.2016].

2 J. Elkington, Cannibals with Forks: The Triple Bottom Line of $21^{\text {st }}$ Century Business, Capstone Publishing Limited, Oxford 1997.

3 A. Witek-Crabb, Zrównoważony rozwój przedsiębiorstw w praktyce gospodarczej, [w:] R. Pajda (red.), Wybrane zagadnienia współczesnej ekonomii. Materiały Konferencyjne AGH w Krakowie, Kraków 2001, s. 152-159. 
do powiązania społecznej odpowiedzialności biznesu i koncepcji zrównoważonego rozwoju, który to przecież oparty jest na trzech filarach: społeczeństwie, gospodarce i środowisku.

Zastosowanie się firm do wytycznych zrównoważonego rozwoju stanowi obecnie duże wyzwanie. Podstawowym problemem, z jakim spotykają się przedsiębiorstwa to kwestie związane $\mathrm{z}$ niszczeniem środowiska naturalnego. W związku z tym firmy, starają się znaleźć coraz nowsze rozwiązania technologiczne czy konstrukcyjne, modyfikują swoje procesy, stawiają na zrównoważone łańcuchy dostaw. Wszystkie te aspekty są istotne, jednak zwykle wiążą się z koniecznością posiadania dużych nakładów finansowych. Co w przypadku, kiedy firma, nie może sobie na takie wydatki pozwolić? Z pomocą przychodzi gospodarka okrężna o obiegu zamkniętym, która jest „odpowiedzią na globalny kryzys ekonomiczny i środowiskowy"4.

\section{Gospodarka okrężna}

Podstawowa zasada funkcjonowania gospodarki okrężnej bazuje na koncepcji „od kołyski do kołyski” (ang. creadle to creadle). Oznacza to, że dany produkt po zakończonym procesie eksploatacji zostaje wykorzystany ponownie w innej formie. Jest to swego rodzaju „wskrzeszenie” produktu.

Jednym z najważniejszych założeń koncepcji minimalizacja wpływu na środowisko produktów, przede wszystkim poprzez odpowiedni wybór składników i sposób projektowania. Wszystko w taki sposób, aby dany przedmiot mógł być ponownie wykorzystany ${ }^{5}$.

Koncepcja „od kołyski do kołyski” wiąże się z zamkniętym obiegiem surowców. Charakterystycznym elementem jest tu ostatni etap cyklu życia produktu, który powinien być jednocześnie pierwszym etapem cyklu życia innego produktu. Producent powinien także potwierdzić, że użyte surowce i materiały pochodzą z poprzedniego użycia lub zostały odzyskane. Bardzo ważny jest także odpowiedni sposób transportu produktów, cechujący się efektywnością ${ }^{6}$.

4 A. Abec, Ekonomia od kołyski do kołyski, Wspólna Odpowiedzialność. Biznes w mieście, Magazyn Miasta nr 2(8)/2014, Warszawa, 2014.

5 www.odpowiedzialnybiznes.pl/hasla-encyklopedii/gospodarka-okrezna-circular-economy [dostęp online: 1.06.2016].

6 P. Hąbek, Zrównoważone wytwarzanie egzemplifikacją koncepcji CSR w obszarze produkcji, www.delibra.bg.polsl.pl/Content/27315/BCPS_31049_-_Zrownowazone-wytwarz_0000.pdf. [dostęp online: 1.06.2016]. 
Metodę „od kołyski do kołyski” można zastosować także w sposobie pakowania produktów. Wówczas szczególną uwagę należy zwrócić na następujące elementy: ${ }^{7}$

- stosowanie opakowań biodegradowalnych, które po wyrzuceniu wbudowują się w składniki glebowe, co będzie miało pozytywny, a nie negatywny skutek,

- stosowanie odpowiedniej ilości opakowań,

- opakowanie ma stać się technicznym lub biologicznym składnikiem po pierwszym wykorzystaniu, wpływa to także na pozytywny odbiór produktu przez klienta,

- dobór właściwych dodatków i barwników, opakowanie może być tańsze podczas prowadzenia recyclingu.

Jak można zauważyć koncepcja „od kołyski do kołyski”, z którą wiąże się ekonomia okrężna, może być realizowana w wielu aspektach działalności przedsiębiorstwa, m.in. w procesie projektowania i produkcji, ale także w logistyce i transporcie wyrobów danego przedsiębiorstwa.

\section{Recycling a upcycling w TSL}

Branża TSL to sektor, który nieustannie kojarzony jest $\mathrm{z}$ negatywnym wpływem na środowisko. Dzieje się tak z uwagi na znaczną ilość odpadów, jakie produkowane są podczas łańcuchów dostaw czy samej eksploatacji pojazdów. Zainteresowanie ochroną środowiska w logistyce pozwoliło w pełni rozwinąć się jej dziedzinie, jaką stanowi logistyka odzysku. Działanie logistyki odzysku opiera się na zasadzie PDCA (ang. plan-do-check-act), czyli idei planowania działań środowiskowych, wdrażania, sprawdzania ich wpływu na środowisko, społeczeństwo i gospodarkę oraz poprawa aktywności w celu nieustannego dążenia do ulepszeńn $^{8}$. W myśl tej zasady powszechnym stało się stosowanie recyclingu, któremu poddawane są głównie materiały używane do produkcji opakowań. Pomimo, że proces ten przynosi wiele zalet, wraz ze wzrostem zainteresowania społeczeństwa aspektami ekologicznymi przedsiębiorstwa zaczęly stosować także wyższą formę recyclingu, którą jest upcycling. W jaki sposób można jednak połączyć proces tworzenia produktu o wyż-

7 B. Ziółkowski, Ekoefektywność w kontekście zarządzania strategicznego, [w:] A. Kaleta (red.), K. Moszkowicz (red.), Zarządzanie strategiczne w badaniach teoretycznych i w praktyce, Prace Naukowe UE w Wrocławiu nr 20, Wrocław 2008, s. 490-497, za: por. M. Braungart, W. McDonough, A. Bollinger, Cra-dle-to-cradle design: creating healthy emissions - a strategy for eco-effective product and system design, Journal of Cleaner Production 15(13-14), 2007, 1337-1348.

8 K. Michniewska, Nowe trendy w logistyce: logistyka odzysku a ekologistyka, Czasopismo Logistyka nr 1/2006, Instytut Logistyki I Magazynowania, Poznań, 2006.

9 P.R. Murphy, D.F. Wood, Nowoczesna logistyka, Wydawnictwo Helion, Gliwice, 2011. 
szej wartości z tzw. „logistycznych śmieci”? Pomimo pozornego braku odpowiedzi na to pytanie, $\mathrm{z}$ dobrych praktyk firm wynika, że zastosowanie upcyclingu do produktów pochodzących z logistyki i branży automotive staje się coraz bardziej popularne. Przykłady jego wykorzystania zostały zaprezentowane w kolejnym podrozdziale.

\section{Odpowiedzialne odpady logistyczne, jako nowe produkty o wyższej wartości - przykłady}

Aby dobrze zrozumieć ideę stosowania upcyclingu w praktyce należy skupić się na jego podstawowej zasadzie, która zakłada, że zużyta rzecz, może być nowym produktem o wyższej wartości. Wyższa wartość polega w tym przypadku na dwóch aspektach. Pierwszy z nich wiąże się z jakością produktów.

Przedmioty pochodzące $\mathrm{z}$ upcyclingu często traktowane są $\mathrm{z}$ o wiele większym kunsztem i artyzmem ${ }^{10}$. Ponadto produkowane są w małych, zwykle limitowanych - z przyczyn technicznych - seriach. Są także unikatowe, ponieważ stopień zużycia danego produktu w jego poprzednim cyklu życia będzie zróżnicowany dla każdego ze stosowanych do upcyclingu przedmiotach. Drugi z aspektów to historia związana z pochodzeniem danego przedmiotu. Jego wartość wzrasta wraz ze świadomością, że jest to produkt $\mathrm{z}$ interesującym zastosowaniem $\mathrm{w}$ przeszłości, ale także $\mathrm{z}$ wiedzą, że powstał on w oparciu o zasady zrównoważonego rozwoju, które to stają się dla społeczeństwa coraz ważniejsze.

Produkty upcykling-owe to głównie przedmioty użytkowe, bazujące na naturalnych, ekologicznych materiałach. Do przedmiotów najbardziej znanych zaliczyć można wszystkie te, które są obiektami pochodzącymi z przekształcenia palet stosowanych w logistyce w nowe wyroby. Obecnie, dużym zainteresowaniem cieszą się meble wykonywane $\mathrm{z}$ palet. $\mathrm{W}$ ofercie znaleźć można zarówno meble domowe jak i ogrodowe. Ponadto z palet wykonywane są także kwietniki, skrzynie na narzędzia czy artykuły dla dzieci takie jak huśtawki. Należy wspomnieć o tym, że palety dają wiele możliwości zastosowań. Ich deski mogą posłużyć także jako panele podłogowe, boazeria czy ogrodzenia.

Drugą z możliwości zastosowania materiału pochodzącego z logistyki do upcyclingu są plandeki pochodzące $\mathrm{z}$ naczep pojazdów ciężarowych. Plandeki to produkt, który podczas transportu łatwo ulega uszkodzeniom, często bywa rozrywany czy poprzecinany. Możliwa jest jego naprawa i regeneracja wówczas, gdy uszkodzenie obejmuje niewielkie partie materiałów, w przy-

10 www.dailykos.com/story/2014/1/12/1269173/-Can-Upcycling-lead-to-real-change-or-do-we-need-an-Economy-for-the-Common-Good [dostęp online: 1.06.2016]. 
padku większych zwykle pojawia się konieczność zakupu nowej plandeki. Dlatego też istotnym było znalezienie sposobu na wykorzystanie go w alternatywny sposób. Sposobem tym jest produkowanie toreb i kosmetyczek, które wytworzone są ze zużytych plandek. Artykuły te cechuje nieprzecięty design - zwykle nie jest możliwe znalezienie dwóch takich samych rzeczy. Ponadto torby mogą być także wyposażone w trzeci przykład materiałów, jakim są pasy bezpieczeństwa. Zużyte, często pochodzące z pojazdów powypadkowych pasy używane są jako wytrzymałe uchwyty do toreb.

Innym materiałem do produkcji palet, może być kolejny element pochodzący z logistyki, którym są worki na listy. Każdy z nich posiada ponadto swój indywidualny numer, co z pewnością stanowi o unikatowej wartości produktu.

Przykładami z branży automotive może być zastosowanie podzespołów pojazdów do produkcji mebli i prezentowanie ich $\mathrm{w}$ formie muzeum. Najczęściej wykorzystywane są bloki silników, skrzynie biegów wraz $\mathrm{z}$ pozostałymi elementami układu przeniesienia napędu, elementy zawieszeń czy fragmenty karoserii.

Równie popularne jest także wykorzystywanie opon samochodowych jako mebli, akcesoriów ogrodowych, akcesoriów dla zwierząt (legowiska), parkingowych (stojaki na rowery), oświetlenia (lampy). Opony rowerowe służą zwykle jako materiał na torebki lub donice.

Powyższe przykłady stanowią jedynie kilka możliwości zastosowania upcyclingu $\mathrm{w}$ branżach TSL czy automotive. W obu sektorach istnieje jeszcze wiele odpadów, które zasługują na nadanie im nowej formy, w zależności od kreatywności autorów projektów i wzrostu zainteresowania ideą upcyclingu wśród społeczeństwa.

\section{Podsumowanie}

Ekonomia okrężna znajduje swoje zastosowanie w wielu aspektach życia, często, jako uczestnicy społeczeństwa spotykamy produkty, które powstały zgodnie z koncepcją „od kołyski do kołyski”. Wiele z założeń wspomnianej idei znajduje swoje zastosowanie nie tylko $\mathrm{w}$ produkcji i projektowaniu różnego rodzaju przedmiotów, ale także $\mathrm{w}$ transporcie, logistyce, czy też zarządzaniu.

Postępujące zanieczyszczenie środowiska i jego degradacja, coraz bardziej zachęcają do podejmowania działań mających na celu przeciwdziałanie tym zjawiskom i promocję postaw proekologicznych. Ważna jest tutaj rola przedsiębiorstw, które również w swojej działalności powinny szczególną uwagę przywiązywać do kwestii środowiska naturalnego, jest to bowiem nie tylko jeden z filarów zrównoważonego rozwoju, ale także dziedzictwo, które przekazujemy kolejnym pokoleniom. 
Organizacje mogą realizować koncepcje społecznej odpowiedzialności biznesu i koncepcję zrównoważonego rozwoju na kilka różnych sposobów, jednym $\mathrm{z}$ nich jest właśnie dostosowanie produkcji do założeń filozofii „od kołyski do kołyski”, a więc wykorzystywanie materiałów odzyskanych, produkcja wyrobów, które będą mogły być później poddawane np. recyclingowi, czy też stosowanie efektywnego transportu i odpowiednie kształtowanie łańcuchów dostaw. Jest to coraz bardziej popularna postawa wpisująca się w dążenie do zrównoważonego rozwoju społeczno-gospodarczego. 


\section{Bibliografia}

\section{Literatura książkowa}

Abec A., Ekonomia od kołyski do kołyski, Wspólna Odpowiedzialność. Biznes w mieście, Magazyn Miasta nr 2(8)/2014, Warszawa, 2014.

Elkington J., Cannibals with Forks: The Triple Bottom Line of $21^{\text {st }}$ Century Business. Capstone Publishing Limited, Oxford, 1997.

Fleischmann M., Bloemhof-Ruwaard J., R. Dekker, van der Laan, E., van J.A.E.E. Nunen and van L.N. Wassenhove, Quantitative models for reverse logistics: a review, European Journal of Operational Research, Vol. 103 No. 1/1997, [w:] R.S. Tibben-Lembke, D.S. Rogers, Differences between forward and reverse logistics, Supply Chain Management: An International Journal, Volume 7, Number 5/2002.

Michniewska K., Nowe trendy w logistyce: logistyka odzysku a ekologistyka, Czasopismo Logistyka nr 1/2006, Instytut Logistyki i Magazynowania, Poznań, 2006.

\section{Źródła internetowe}

www.dailykos.com

www.odpowiedzialnafirma.pl

www.delibra.bg.polsl.pl
Murphy P.R, Wood D.F., Nowoczesna logistyka, Wydawnictwo Helion, Gliwice, 2011.

Witek-Crabb A., Zrównoważony rozwój przedsiębiorstw w praktyce gospodarczej, [w:] R. Pajda (red.), Wybrane zagadnienia współczesnej ekonomii. Materiały Konferencyjne AGH w Krakowie, Kraków, 2001.

Ziółkowski B., Ekoefektywność w kontekście zarządzania strategicznego, [w:] A. Kaleta (red.), K. Moszkowicz (red.), Zarządzanie strategiczne w badaniach teoretycznych i w praktyce, Prace Naukowe UE w Wrocławiu nr 20, Wrocław 2008, za: por. M. Braungart, W. McDonough, A. Bollinger, Cra-dle-tocradle design: creating healthy emissions a strategy for eco-effective product and system design, Journal of Cleaner Production 15 (13-14), 2007, 1337-1348. 